\title{
\begin{tabular}{l|l|l|} 
Sniversity of & FOUNDED \\
St Andrews & 1413
\end{tabular}
}

University

Library

\section{From the Vite or the Ritratti? Previously unknown portraits from Vasari's Libro de' Disegni}

\author{
Moretti, Laura \& Roberts, Sean
}

\begin{tabular}{|l|l|}
\hline Date of deposit & 05/10/2017 \\
\hline Document version & Author's accepted manuscript \\
\hline Access rights & $\begin{array}{l}\text { C) } 2018 \text { by Villa I Tatti: The Harvard University Center for Italian } \\
\text { Renaissance Studies. All rights reserved. This work is made } \\
\text { available online in accordance with the publisher's policies. This is } \\
\text { the author created, accepted version manuscript following peer } \\
\text { review and may differ slightly from the final published version. } \\
\text { This manuscript contains the text only, to view the images } \\
\text { referred to please consult the final published version. }\end{array}$ \\
\hline $\begin{array}{l}\text { Citation for } \\
\text { published version }\end{array}$ & $\begin{array}{l}\text { Moretti, L., \& Roberts, S. (2018). From the Vite or the Ritratti? } \\
\text { Previously unknown portraits from Vasari's Libro de' Disegni. I } \\
\text { Tatti Studies, 21(1), 105-136. }\end{array}$ \\
\hline $\begin{array}{l}\text { Link to published } \\
\text { version }\end{array}$ & \begin{tabular}{l} 
https://dx.doi.org/10.1086/697035 \\
\hline
\end{tabular}
\end{tabular}

Full metadata for this item is available in St Andrews Research

Repository at: https://research-repository.st-andrews.ac.uk/

\section{St Andrews Research Repository}




\section{From the Vite or the Ritratti?}

\section{Previously Unknown Portraits from Vasari's Libro de’ Disegni}

The process of producing woodcut portraits to illustrate the second edition of Giorgio Vasari's Vite, published in Florence by the Giunti in 1568, was laborious, long, and complicated. ${ }^{1}$ From his correspondence with the historian and collector Paolo Giovio, it is possible to gather that the Aretine harbored ambitions for such illustrations for the publication in 1550 of the first edition of his book by Lorenzo Torrentino, and was already considering prototypes for such portraits at that time. ${ }^{2}$ Cutting of the blocks the works of an artisan identified only as "maestro Cristofano" in the life of Marcantonio Raimondi ${ }^{3}$ - began in Venice in $1560^{4}$ and continued until at least the autumn of $1567 . .^{5}$ The diplomat and humanist Cosimo Bartoli, who served as Cosimo I de Medici's agent in Venice, acted as an intermediary and oversaw the blocks' production. ${ }^{6}$

From a few surviving letters it is possible to gain some understanding of how the operation proceeded. Vasari and his collaborators, reliant on a variety of iconographic sources, produced the preparatory drawings in Florence. ${ }^{7}$ The work progressed gradually over a period of years: Bartoli repeatedly solicited new drawings from Vasari, as is indicated in letters of 1563,1564 , and $1567 .{ }^{8}$ Vasari's self-portrait, which appears last in the series within the printed edition, was only completed on the $20^{\text {th }}$ of September, $1567 .{ }^{9}$ A few examples of the preparatory drawings, presumably by Vasari's own hand, are preserved today in the Gabinetto Disegni e Stampe degli Uffizi (hereafter GDSU) (Fig. 1). ${ }^{10}$ The drawings were transferred onto the wood blocks in Florence, a process for which Vasari took personal credit, on at least one occasion. ${ }^{11}$ Though this must have made their shipment to Venice significantly more cumbersome, 
it is clear that Vasari and his workshop left nothing to chance. Thus prepared, the blocks were next sent to Bartoli in Venice, who passed them on to Cristofano to cut. ${ }^{12}$ Having checked the quality of the finished work and having paid the cutter, Bartoli then sent the blocks back to Florence, ${ }^{13}$ where they were delivered to the publisher. Proofs of the portraits were printed by the Giunti and sent for inspection to Vasari, along with - at least in some cases - Vincenzo Borghini. ${ }^{14}$ With these test images approved, the assembled blocks were integrated with the letterpress text in the form (or chase) of the press and the pages of the Vite were printed (Fig. 2).

The Giuntina edition included a total of 144 such portraits. Each is rendered bust-length in an oval format, enclosed within an elaborate, classicizing architectural frame including allegorical figures indicating the particular artistic abilities of the sitter. Six distinct types of frames were produced to embellish these illustrious faces. Three of these correspond respectively to the arts of painting, sculpture, and architecture, two provide combinations of two of those arts, and the last refers to the three arts of disegno. Surviving preparatory drawings attributed to Vasari's hand demonstrate his personal concern for these framing devices. ${ }^{15}$ One of the frames, the oval portrait of the artist, and the name of the sitter were combined at the time of their printing to produce each finished image. An additional eight empty frames were printed without portraits for Pietro Cavallini, Giovanni da Ponte, Barna da Siena, Duccio, Taddeo di Bartolo, Antonio da Correggio, Pietro Torrigiano and Marco Calavrese. It is clear that he took the search for prototypical portraits of his artists with great seriousness. Though in some the cases the portrait is missing entirely, in at least these eight examples, Vasari considered a blank frame superior to a fictive or generic portrait. ${ }^{16}$ Expensive and labor intensive, the production of these portraits must have represented a significant investment on the part of Vasari and his printer. The Giunti press, for its 
part, sought inventive ways to capitalize on the blocks. ${ }^{17}$ Apart from their obvious inclusion within the Vite, the complete series of portraits - without the corresponding biographies - was issued by the Giunti in 1568 as the Ritratti de' più eccellenti pittori, scultori et architetti. Contenuti nelle vite di M. Giorgio Vasari Pittore, \& Architetto Aretino (Fig. 3). ${ }^{18}$ The same printing house, recognizing a potential commercial opportunity, also published in that year Vasari's Vita di Michelangelo as a slim, standalone booklet, reusing the Vite's portrait of the artist. ${ }^{19}$ Moreover, the success of the Vite lent these images an authority that kept them commercially viable for successive generations of readers and viewers. When the Giunti printed Vasari's Trattato della pittura in 1619, it was from these same blocks - now showing signs of wear and tear - that his portrait was pulled. ${ }^{20}$

Nor did the life of the blocks come to an end with the closure of their original publishing house in $1625 .^{21}$ Instead, the complete series of the oval portraits, under the title Effigie di celebri pittori, scultori et architetti la cui vita fu descritta dal signor Giorgio Vasari, was published in 1629, again in Florence but this time by Simone Ciotti, who states in the dedicatory letter that he had come into possession of the blocks (Fig. 4). ${ }^{22}$ As with the Ritratti, the publication contained no text, except in the Effigie a brief introductory dedication. Over the next two decades, the blocks made their way some sixty miles to the north, to Bologna. For in 1647 the heirs of Evangelista Dozza published a new edition of the Vite in that city, with a commentary by Carlo Manolessi. ${ }^{23}$ Once more, the full series of portraits was included, albeit with a few variations, necessitated by damage and loss to the now ninety-year old wood. Judging by the quality of these prints, the blocks must have been in quite poor condition by this point, and this was, in all likelihood, the last time they were used (Fig. 5). 
Yet a further purpose to which some of these woodcuts were used can be observed on the pages of the so-called Libro de' disegni, the collection of drawings which Vasari was starting to assemble at least by $1528^{24}$ and which continued to expand until his death. ${ }^{25}$ Though he referred to the project as a "libro" - first of all in the pages of the Vite - it was rather a set of albums, and while some scholars estimate that around 1000 to 2000 individual drawings were included, no contemporary inventory of the collection was made, and even the number of albums remains a matter of conjecture. ${ }^{26}$ Partially dispersed at the time of Vasari's death, the remnants of this collection survive in several institutions today and include many of the most significant extant Renaissance drawings, especially of the Florentine school. In Vasari's day, these drawings were situated within elaborate architectural frames executed in pen and watercolor on oversized sheets. ${ }^{27}$ Each of these folia gathered drawings that were attributed to a single draughtsman and in many cases he took care to identify the artist with a hand-written label within these frames. While most of the pages have been disarticulated by subsequent collectors and conservators, often eager to substitute their own up-to-date attributions for those of Vasari, a handful of the sheets remain intact today. Woodcut portraits are affixed to nine integral sheets recognised as deriving from the Libro, today held in the British Museum, Christ Church College, Oxford (Fig. 6), the École des Beaux-Arts, Paris, Louvre, and at Chatsworth. ${ }^{28}$ Cropped quite closely, but irregularly, around the architectural frames, these prints are generally integrated near the top center of each of the pages. They are harmoniously incorporated into the sheet's elaborate framing devices both with pen and through the addition of watercolor for shading and modeling. Often these additions serve to continue the architectural elements of the drawn frames onto the print. The upper left and right edges of Filippino Lippi's portrait (Fig. 7), for instance, include extensions of the gently arched pediment 
rendered in pen and wash above the print. ${ }^{29}$ The woodcut portraits employed on these pages are usually referred to as having been cut from copies of the Vite or - more recently - the Ritratti. ${ }^{30}$

In what follows here, new analysis is provided - and a significant new discovery in the collections of the Uffizi is introduced - regarding the use and function of these woodcuts in the Ritratti, the Vite and the Libro de' disegni. In the process, new light will be shed too on the complex and still misunderstood relationship between these interconnected projects.

\section{The Ritratti}

If the Giuntina edition of the Vite is one of the best known and most studied books of the Renaissance, the Ritratti has attracted only modest attention. ${ }^{31}$ This is due, in part, to the fact that only three copies are known today. These are held at the Biblioteca Berenson at Villa I Tatti, Harvard University's Houghton Library, and at the New York Public Library. ${ }^{32}$ Each book presents all 152 woodcuts - including the eight empty frames - appearing in the Giuntina Vite. Each leaf is dedicated to a single woodcut, and in all cases these are printed on only one side of the sheet. The volume is initiated with a title page and concluded with a final woodcut, variants of those employed within the Vite. An index of each of the included portraits completes the book.

This operation can be seen as part of a larger trend - that of collections of portraits of illustrious men and women, almost always based on collections of paintings, coins and medals, and other iconographic material - which flourished in the second half of the 1560s and saw numerous publications, particularly in Rome and Venice. To name but a few, Antoine Lafréry published in Rome an Illustrium iureconsultorum imagines from the Paduan portrait collection of the jurist Marco Mantova Benavides (1566), the 
Pontificorum maximorum elogia et imagines (1568), and the Imagines et elogia virorum illustrium et eruditor, from the library of Fulvio Orsini (1570). Venice, meanwhile, saw the publications of the Immagini delle donne auguste intagliate in rame of Enea Vico (1557) and a bit later, another edition of the Illustrium iureconsultorum imagines (1569) from Benavides collection. ${ }^{33}$ Like the Ritratti, these publications are generally known today in a small number of copies.

In all three extant copies of the Ritratti, the portraits are printed on paper of varying thickness and weight, without apparent rationale. Likewise, the images appear at various heights on the page, again without clear reason since the positions do not necessarily correspond to those within the Giuntina edition of the Vite where their position relative to the text was a limiting factor. Each portrait is numbered - just below the frame - and in some cases those numbers have been corrected by hand in pen. Clearly these numerals were inserted after the portraits were put in order, a process made simple thanks to the index. Though included in a 1604 list of books published by the Giunti shop and present in their archive, the Ritratti was composed using neither the structure nor the techniques often employed for a commercial quarto edition. ${ }^{34}$ A certain degree of variation must be expected in sixteenth-century editions. Nonetheless, most such books were organized and collated at the printer's shop with the aid of printed page numbers and quire signatures. A project like the 1568 Vite would have involved printing four pages, combining letterpress text and image, on each side of folio for a total of eight pages per sheet. ${ }^{35}$ In contrast, the individual pages of the Ritratti were not produced through such systematic folding, but were rather printed on a single side of the sheet and cut apart. They were then glued together, one by one, and gathered in a very simple binding. 
Though the extant copies of the Ritratti share a great deal of technical characteristics in common, they also present some minor variations. The New York Public Library and Houghton copies are a bit more cohesive in their organization than the example in Florence. The Biblioteca Berenson's Ritratti was gathered and bound with the portraits haphazardly occupying either side of the page (Fig. 3). Opening that copy at random, the viewer might encounter a spread of two portraits, a single portrait on a recto or verso, or simply a blank recto and verso. The binders of the other two examples, in contrast, glued each of the pages together such that the printed portraits appear on the recto of each page. All three examples employ the same type of binding, with four laces attached for closure. The binding techniques varied slightly, particularly in the New York copy, but no significant differences can be found in their structure.

A few differences can be observed between these portraits and those included in the Giuntina Vite. While the oval portraits proper are, in all cases identical, their combination within the available frames and especially the composition of their labels sometimes varies from their counterparts in the Vite. For example, while Lorenzo Ghiberti appears within the frame reserved for painters in the Vite, the Ritratti, more accurately, employs that used for sculptors. ${ }^{36}$ Variations in the labels include differences in the alignment and registration of the artists' names, inclusion or exclusion of punctuation, and different forms of abbreviation. Specific examples of these discrepancies are discussed in greater detail below. For the moment, it is sufficient to note that variations between the Vite and Ritratti are such that it is impossible to clearly establish an exact chronology for the two editions. Though it would be tempting to imagine the Ritratti simply as bound collections of proofs for the Vite's portraits (augmented with a title page, an endpiece and an index) this seems highly unlikely for a 
number reasons. Rather than the Ritratti simply correcting mistakes present in the Vite, as we have seen from the example of Ghiberti above, errors flow in both directions. Significantly, however, these variations are - in almost all cases - uniform among the three extant copies of the Ritratti. Moreover, the text of the Vite was - at least in some cases - already set in type when the Ritratti was printed. Thus, while proofs were probably pulled from the assembled frames, portrait ovals, and possibly labels, the pages of the Ritratti were assembled with the text in chase of the press before printing. At this point, the blocks would have been inked and the type masked using an oiled frisket sheet since even the most careful application of ink could not guarantee that none would be deposited on the text. ${ }^{37}$ While this prevented the unwanted letters from printing on the finished sheet, the tell-tale embossing of that text often nonetheless appears on the pages of the Ritratti, as in the Berenson's portrait of Nanni di Banco, where opening lines of his life are plainly visible. ${ }^{38}$ So too, a few of these portraits include the printed text of the Vite's running head. Those of Cimabue and Arnolfo di Cambio, for instance, prominently display "PRIMA PARTE" above their frames. ${ }^{39}$ The relationship between the Vite and Ritratti was thus a fluid one. Whether the impetus for a collection of the portraits originated with Vasari or the Giunti, the Ritratti represents a consciously planned separate edition and its simultaneous printing with the Vite would have been the most efficient and economical means of realizing the project. Nothing, unfortunately, is known about the original (or even early) owners of the Houghton and Berenson copies, and the books themselves offer no further clues. An annotation on the New York Public Library example, however, offers relevant evidence regarding one of his early owners. Written in brown ink on the title page (Fig. 8) is the name of Giovanni Battista Clarici (1542-1602), an engineer, cartographer, and architect. Born and trained in Urbino, Clarici enjoyed success especially as a designer of 
fortifications throughout Italy. He rose to prominence as a favored military engineer of the peninsula's Hapsburg overlords, working on behalf of Spanish interests in expanding the walls of Cremona and as an integral player in the renovation of Milan's Castello Sforzesco. ${ }^{40}$ By 1587 Clarici's ingenuity was widely praised. The Milanese chronicler Gasparo Bugatti singled him out as the "great surveyor of waterways, rivers and lakes, of fortresses, of mountains and landscape," - an estimation shared by Giovanni Paolo Lomazzo. ${ }^{41}$ Clarici's putative ownership of this copy is made all the more plausible by the fact that he was personally acquainted with Vasari. He had, in fact, met the Aretine during a month-long sojourn in Florence in 1565, at roughly the same moment that the Vite was rolling off the Giunti's presses. A letter dated 24 June of that year, written on the verso of a drawing today in the GDSU, attests that Clarici, on this occasion, visited Vasari's workshop and was acquainted with Marco da Faenza (known as Marchetti), one of the most trusted assistants within the shop. ${ }^{42}$ The engineer's interest in the project that would become that Ritratti might have been kindled at this time. Whether he later purchased his copy from the Giunti or perhaps even received it as a gift from Vasari, we might ask what someone like Clarici have done with this collection of famed artists?

It is possible that copies of the Ritratti, as well as being bound as books - as is demonstrated by the three known examples - could have been used within collections of prints or drawings and later dismembered. ${ }^{43}$ Likewise, pages that comprised these books could have been used as individual prints rather than as part of the complete set. Such diverse patterns of book use were common even when considering a single edition of a printed book throughout the later fifteenth and sixteenth centuries. The usual practice of buying books unbound (though collated) meant that many such decisions were left to the discretion of book buyers rather than printers or sellers, in ways quite foreign to 
modern conceptions of standardized editions. ${ }^{44}$ The Giunti's decision to print the Ritratti on only one side of each sheet was crucial to the modular nature of the project, and facilitated its flexibility for varied uses by divergent buyers.

It is entirely possible, then, that these might be considered a relatively inexpensive and infinitely more portable - version of a portrait gallery. ${ }^{45}$ This developing typology became increasingly more prominent at this point in the sixteenth century by the time of the Ritratti's printing already existed in a number of important examples. These included both 'real' galleries (comprised of paintings) as well as imaginative ones, given, as we have seen, standardized form through their translation by printmakers into books and prints. These latter could have been hung on walls, gathered in albums, or possibly used in a host of other ways. It is perhaps in anticipation of the dismemberment and mounting of these images that so little care was taken by the Giunti in selecting paper stock for this edition. The variations in the thickness of these pages would have made little difference once they were affixed to some other support. Whether Clarici possessed any such collection is unknown. His map of Milan, created for the Spanish survey of 1587 , is the work of a consummate draughtsman and the wide range of surviving plans for fortifications and studies of topography suggest an artist equally at home with pictorial and mathematical demands. ${ }^{46}$ That his surviving letter appears on a sheet of studies attributed to Federico Barocci is one strong indication of his interest in artists' drawings. Likewise, his observation that Marco da Faenza's "seemed to me to work very skillfully in creating grotesques," and his judgement that Florence was so pleasing to him that a month was not nearly enough time adequately acquaint himself with "all of its beautiful works, as many paintings as sculptures," all suggests that the most plausible first owner for a copy of the Ritratti might well have been a man deeply interested in the study and display of works of art. ${ }^{47}$ 


\section{Previously Unknown Portraits}

One problem confronting research on such fictive collections is that these kinds of materials were not generally thought of as especially precious - like 'true' artists' prints - and as such were often not even catalogued in their later repositories. Even when they have been catalogued, it is often inaccurately or incompletely. For example, within the University College London Art Museum's collection there are two portraits cut from a copy of the Vite (they include text printed on their reverse) and mounted on cardboard, which are errantly catalogued as individual portraits. ${ }^{48}$ The existence of such fugitive impressions from the Vite, suggested that examples from the Ritratti might likewise have found their way into collections, classified either as single portraits or as cut from the Vite. The more modular nature of the book - the capacity for its images to be resequenced or individually displayed - hinted that such a fate might well have befallen some copies of the Ritratti. Clarici's volume had remained intact, but it is likely that others had not fared as well. With such possibilities in mind, the location for this continuing research shifted away from the library and toward the prints and drawings department of the museum.

Conserved among the print collection of the GDSU are eight portraits of artists which can be traced back to the Giuntina edition of the Vite, or more accurately - as we shall see in what follows - to the production of the prints used for both the Vite and Ritratti. Considered by the compiler of the card catalog to be "proofs of the woodcuts used for the portraits of the artists in the Giuntina edition of Vasari's Vite" they are gathered together in a medium sized envelope. Included are the portraits of Bramante (cat. no. 12399, Fig. 9), Benedetto da Rovezzano (12400, Fig. 10), Andrea Contucci known as Sansovino (12401, Fig. 11), Desiderio da Settignano (12402, Fig. 12), Baldassare 
Peruzzi (12403, Fig. 13), along with Giuliano (12404, Fig. 14), Bastiano called Aristotile (12405, Fig. 15), and Antonio da Sangallo (12406, Fig. 16). Each is trimmed around the edge of the frame, with the exception of that of Andrea Contucci (Fig. 11), which is instead cut around the oval of the portrait. Each of the images has been mounted on a square of light-brown cardboard. The majority are water-colored, and several also include pen strokes in brown ink. For example, on the portrait of Benedetto da Rovezzano (Fig. 10), these lines accentuate the decorative details of the frame. In many cases, both the watercolor and pen lines seem to have continued beyond the cropped edges. None exhibit printed text on their verso, demonstrating that they were certainly not cut from one or more copies of the Giuntina Vite and suggesting, initially, that they might more closely correspond to those used in the Ritratti. Yet inconsistencies between these images and those of the Vite and Ritratti alike necessitated a closer look.

It is perhaps best to examine these images in detail, one by one, to better place them in relation to the different versions of the published portraits. The portrait of Bramante in this group (Fig. 9) appears within the frame usually reserved for those artists who excelled in the fields of painting and architecture, the same used in both the Ritratti (Fig. 17) and the Vite (Fig. 18). ${ }^{49}$ The images used in both publications do not differ substantially between themselves, and the portrait here is similarly indistinguishable. There are a few similar but not perfectly identical errors in the registration of the letters of the artist's name between the three versions. The portrait of Benedetto da Rovezzano (Fig. 10) is paired with the frame dedicated to sculptors in both the Ritratti (Fig. 19) and Vite (Fig. 20). ${ }^{50}$ The GDSU's woodcut is identical to that which appears in the Ritratti, and presents a few minor variations compared to that of the Vite. For example, those printed in the Vite are missing the period after the word 'SCVLTORE', which is present in 
both those of the GDSU and the Ritratti. The registration of the letters is identical in these latter two versions and differs slightly from that of the Vite.

The portrait of Desiderio da Settignano (Fig. 12), inserted into the frame used for sculptors, however, exhibits a few variations in comparison to that of the Ritratti (Fig. 21) as well as that which appears in the Vite (Fig. 22). These are principally, once again, in the details of the letters' registration for the name and expertise of the sitter. ${ }^{51}$ In another respect, however, this version can be definitively linked with the Ritratti rather than the Vite. The index number used for Desiderio da Settignano in the former publication is 61 . As previously noted, while the portraits in the Ritratti are individually numbered beneath each frame, these numbers are absent in the Vite. Significantly then, at the bottom of Desiderio's portrait we can clearly see a fragment of the number 6 . This is placed in exactly the same position used for the 6 of the 61 under the frame in the Ritratti version and was preserved when this portrait was cut from the paper on which it was printed. Considering the slight difference in the label's registration between this image and those in the extant copies, we can assume that this image was taken from a page or proof sheet intended for the Ritratti.

The portrait of Giuliano da Sangallo (Fig. 14), placed in the frame reserved for architects, is analogous in every way to that appearing in the Ritratti (Fig. 23). ${ }^{52}$ The version used in the Vite (Fig. 24), in contrast, presents variations in both the artist's name and qualifications: "VITA DI GIULIANO ET ANTONIO DA S. GALLO ARCHIT. FIOR." That of Bastiano detto Aristotile da Sangallo (Fig. 15) is placed in the frame used for artists working in the fields of both painting and architecture and is identical with the image included in the Ritratti (Fig. 25), which differs from that of the Vite (Fig. 26) in several respects. ${ }^{53}$ In particular, the frame used for the GDSU example and for the Ritratti both include horizontal breaks on each side - presumably an unintended 
indication of the process by which the two halves of the frame were fitted around the oval portrait. The version published in the Vite, includes only the break on the left. Further, the text within the label is slightly different, and a defect in the printing of the ornament at the bottom edge of the image is found in both the versions of the GDSU and the Ritratti. Likely this occurred when the index number was inserted just below the frame, since, as we have already described, these numbers are absent in the Vite. The variations present in these five woodcuts demonstrate the complexities inherent in printing two different editions simultaneously. Such relatively subtle differences, however, pale when we examine the remaining three images of this group. For though the portraits of Andrea Contucci (Fig. 11), Baldassarre Peruzzi (Fig. 13), and Antonio da Sangallo (Fig. 16) appear at first glance superficially similar to these prints, closer examination reveals that each of these is, at least in part, a drawing. The image of Contucci (Fig. 11) is a pen drawing which closely follows the version of the Vite. We can see that central figure above the frame corresponds to the type usually employed for artists known principally as sculptors and architects, the same which is used for Contucci in both the Ritratti (Fig. 27) and the Vite (Fig. 28). ${ }^{54}$ The handwritten label imitates closely the one in the Vite, which differs from that of the Ritratti. The portrait of Baldassare Peruzzi (Fig. 13) is a hybrid image, consisting of a pen portrait oval drawn within one of the eight blank woodcut frames. The frame does not correspond with that used for that artist in either the Ritratti (Fig. 29) or the Vite (Fig. 30), ${ }^{55}$ where - in agreement with the label beneath the portrait - the type reserved for painters and architects is employed. Here instead the frame usually corresponding to artists known for architecture and sculpture has been used, and the original artist's label has been cut away. Peruzzi's name and profession have been substituted by hand in the label's place, copying the version appearing in the Vite rather than from that of the Ritratti. The final 
portrait in the series, that of Antonio da Sangallo (Fig. 16), is a drawing and departs from the woodcut published in both the Ritratti (Fig. 31) and the Vite (Fig. 32). ${ }^{56}$ Antonio's forehead is more pronounced in the drawing and his nose is slightly more crooked. The artist, in all three versions, is portrayed within the frame used for architects, but the GDSU drawing seems calculated to emphasize, or even exaggerate, a few distinctive characteristic of the woodcuts: the draughtsman has included two horizontal breaks at the edges of the frame, in imitation of the defects mentioned in the portrait of Bastiano detto Aristotile (Fig. 15), which are instead absent in the printed versions of Antonio da Sangallo's portrait. The drawing was calculated, in other words, to seem more like a print than the print its author used as his model.

It is difficult, if not impossible, to trace the authorship of these drawings with certainty. Though they were executed by an undoubtedly talented artist, their author's dedication to imitating his woodcut models makes their attribution a daunting task. But we will return to this question in greater detail toward the end of the article, with some additional considerations.

\section{The Libro de' Disegni}

The treatment of these portraits is, in all ways, comparable to that seen on the nine pages deriving from Vasari's Libro de' disegni previously mentioned. An album of drawings traditionally regarded as derived from Giorgio Vasari's collection was acquired in 1798 from Grand Duke Ferdinando III for the Florentine state collections. Then director Tommaso Puccini penned a lengthy report, in which he described the contents of the album. ${ }^{57}$ According to this document, the volume contained 107 large architectural drawings and other of smaller dimensions, along with twenty-one figure drawings, which were gathered on both the recto and verso of the 
pages. Among the authors of these drawings mentioned by Puccini "omitting those of lesser reputation” were Francesco di Giorgio (1 drawing), Baldassare Peruzzi (2), Bramante (10), Fra Giocondo (1), Andrea Contucci detto il Sansovino (7), Benedetto da Rovezzano (2), Desiderio da Settignano (1), Antonio Labacco (2), Giuliano (17), Antonio (24), Francesco (6), and Aristotile (1) da Sangallo, and Vincenzo Scamozzi (3). The subjects of these drawings included proposed projects for Saint Peter's by Bramante and Giuliano da Sangallo, capitals and moldings drawn from the antique, the plan for the Procuratie Nuove of Venice, as well as one for Giuliano da Sangallo's never realized Medici palace on via della Crocetta. ${ }^{58}$ Puccini harbored no doubts about the album's provenance: "The majority and best of these drawings belonged to Giorgio Vasari, who, as he attested at the end of almost all of his lives of the artists, assembled a great album, which was, for the most part, destroyed and dispersed [...]. Proof of this is found in the watercolor decoration by Giorgio himself executed with great skill around each of its sheets, along with the portrait of the artist to whom the drawing was assigned. I remember having seen a few such examples in the collection of the Dutch Baron Lestewenon, ${ }^{59}$ which he had acquired at great expense from the Mariette sale and which he held as especially precious." 60

So, when the drawings entered the collection, they were mounted on the album's pages, surrounded by frames and enhanced with watercolor ornaments, along with - at least in some cases - a woodcut portrait of the artist to whom they were attributed. It was this supporting apparatus that suggested to Puccini the volume's provenance from Vasari's famed collection. Though the director provided no more detailed description, we can assume that the pages looked quite similar to the sheet today in Oxford (Fig. 6). ${ }^{61}$ Though Puccini did not reveal his identity, he included a few details that have provided a basis for identifying the album's former owner. This was Séroux d'Agincourt, who 
had acquired the volume at the sale of Mariette's estate in $1775 .^{62}$ The fact that the album contained woodcut portraits of the artists represented is confirmed by the catalog from this sale where it is listed as " 1408 . Another great folio volume of sixty sheets, bound in natural calf and containing more than a hundred difference architectural drawings and studies of figures, rendered in pen and watercolor, by Antonio and Giulio da Sangallo and other Florentine architects and sculptors, along with their portraits mounted at the top." 63

Nothing more is known about the provenance of these materials. The album was dismembered when it entered the Florentine gallery and the individual drawings were catalogued according to author by curators at that time. If several scholars have attempted to attest the Vasarian provenance of this album and to determine which drawings in the GDSU formed part of it, to the best of our knowledge, no one has previously shown any interest in these woodcut portraits of the artists originally mounted together with the drawings on some of the sheets. ${ }^{64}$ Along with giving further insight into the use of prints connected with the production of the Ritratti and the Vite, these newly recognized portraits provide supporting evidence that the drawings forming part of the album which entered the GDSU collection in 1798 might indeed have belonged - at least in part - to Vasari's own collection.

The newly discovered portraits in the GDSU, as we discussed above, might be classified as proofs, though it is also possible that some were remainder impressions leftover from the Ritratti's production. The fact that several of these images fail to conform - albeit in sometimes apparently minor details - to those of either the Vite or the Ritratti, all but insure that this must have been the case. Access to such proofs would have been limited to Vasari and a few of his closest collaborators. That these trial impressions, rather than 
examples cut from the commercially available editions, were integrated into the fabric of the Libro, and in the sheets which reached the GDSU in 1798 - evident from the fragmentary pen and watercolor embellishments present on these images - provides compelling confirmation of the personal role Vasari, rather than later owners like Niccolò Gaddi, ${ }^{65}$ played in creating the decorative apparatus and structure of the Libro's pages. So too, the fact that the woodcuts employed in the GDSU group conform so closely to those employed on the extant sheets derived from Vasari's own collection provides significant reinforcement for Puccini’s judgement of their provenance. Their incorporation suggests, moreover, the ways in which the Vite, Ritratti, and Vasari's collection of drawings evolved together over a period of almost two decades. When the Vite were published in 1550 , their author made no mention of his collection of drawings. By 1568, however the Libro, clearly a coherent project in Vasari's mind, is everywhere apparent. The production of the woodcut portraits for the revised Vite was only one part of a lengthy process that gave Vasari ample time to ruminate on the shape of his growing collection of drawings and its relationship to his planned publications. This fecund period witnessed the conception and development of his Libro and it may even have been this use of some of these proofs within his albums, and the possibility that other collectors might find portraits similarly useful, that gave him the idea for the Ritratti in the first place. ${ }^{66}$

If these portraits accord, in many ways, with previous conceptions of the relationship between prints and drawings within Vasari's collection, they also present unique characteristics that offer new insights into the complexity of these arrangements. First and foremost, the presence of drawn portraits imitating those of the Ritratti and the Vite have no parallel in other extant pages from the albums. Likely, the drawings of Andrea Contucci, Baldassarre Peruzzi, and Antonio da Sangallo were created in lieu of 
available proofs at the moment of their incorporation into the Libro. Their often careful imitation of the graphic conventions of woodcut, then, provided a level of uniformity that might otherwise have been absent from the collection. The addition of more traditional drawings might have disrupted the composition of the page, leading to the misinterpretation that the portrait was by the hand of the artist whose works were collected there. Perhaps, most significantly, it seems likely that Vasari - or an artist so close as to be indistinguishable from the master's own hand - drew these fascinating and playful mock prints. By his own account in the Vite, Vasari owned drawings by at least six of the eight artists of the GDSU group by $1568 .{ }^{67}$ The sheets to which these portraits were attached might have been in his possession over the course of the years during which the images for the Vite and Ritratti were being cut, printed, and approved. Likewise, the drawn portraits of the GDSU compare favorably with closely contemporary drawings associated with Vasari's hand in the collection. ${ }^{68}$ An exhaustive stylistic comparison is beyond the scope of the present study, but a favorable parallel might be drawn with a study for a frontispiece by the master's hand, today GDSU, 394 O (Fig. 33) ${ }^{69}$ To use but one example, the morphology of the feet of the figures perched atop the curving pediment here - the angular foreshortening of the whole form, the high, almost twisted arch of the rear foot, combined with discrete, curvilinear toes accords closely with that of the figure of Architecture drawn above the frame for Antonio da Sangallo's portrait. There is here too a softness in Architecture's facial features, a gentle swelling and fullness of her lips, which stands in contrast to her necessarily more schematic, and hard edged companion above the printed frame, seen in this group's portrait of Giuliano da Sangallo (Fig. 14). Far from a second-rate copy of the woodcut original, this sophisticated imitation of a print, is every bit the equal of Vasari's known drawings. Like the use of the variant woodcut portraits, the high quality 
of this draftsmanship provides further evidence that the sheets incorporated into the Uffizi's collection in 1798 might have been assembled with Vasari’s personal involvement.

A more direct comparison is provided by the drawn portrait of Peruzzi (Fig. 13) and the woodcut version that appeared in the Vite (Fig. 30). The close correspondence between the swelling, tapered lines that serve both to create a sense of depth in fictive space of the oval and to model the folds of the artist's shirt is striking. These are not the product of tracing but rather signs of the same draughtsman at home in his chosen graphic idiom. These similarities suggest that the artist responsible for this drawing - whether Vasari or a very talented assistant - might well be the same individual who transferred Peruzzi's portrait to the woodblock.

Vasari's project of accumulation grew from a small nucleus of drawings to encompass, by the end of his life, a massive corpus. The Libro - and this was Vasari's name for this undertaking even when it came to fill several such volumes - came to serve as a kind of visual parallel to his written biographies. The integration of woodcut portraits onto these pages represents perhaps the most direct means by which he signaled the interconnectedness of these joint endeavors which occupied so much of his energy. The eight previously unknown portraits from these volumes discussed here - drawings, woodcuts, and hybrid combinations of these - both expand our knowledge of one of the most pivotal of early modern collections, and provide a fascinating glimpse into the once unsuspected sophistication of Vasari's negotiation of prints and drawing, singular and multiple, within his practice. 


\section{Notes}

${ }^{1}$ The bibliography on this subject is extensive. See, among others, Licia Collobi Ragghianti, “Il 'Libro de' disegni' ed i ritratti per le 'Vite' del Vasari," Critica d'arte, n. s., XVIII/117 (1971): 37-64; Julian Kliemann, “Le xilografie delle Vite del Vasari," in Giorgio Vasari. Principi, letterati e artisti nelle carte di Giorgio Vasari, eds. Laura Corti and Margaret Daly Davis (Florence, 1981), 237-63; and, more recently, Barbara Stoltz, “Disegno versus Disegno stampato: printmaking theory in Vasari’s Vite (15501568 ) in the context of the theory of disegno and the Libro de' Disegni," Journal of Art Historiography 7 (2012), URL:

https://arthistoriography.files.wordpress.com/2012/12/stoltz.pdf (accessed on 10 February 2017); Sharon Gregory, Vasari and the Renaissance Print (Farnham, 2012), 83-114. The iconographic sources for the portraits were studied in detail by Wolfram Prinz, "Vasaris Sammlung von Künstlerbildnisses: mit einem kritishen Verzeichnis der 144 Vitenbildnisse in der zweiten Ausgabe der Lebensbeschreibungen von 1568," Mitteilungen des Kunsthistorischen Institutes in Florenz 12 (1966): 1-158.

${ }^{2}$ Letter by Paolo Giovio to Giorgio Vasari, 31 March 1548: "La vostra lettera mi è stata molto cara e se stamperete l'opera senza figure, per non perdere tempo e denari, vi darà onor in vita e dopo morte.” Arezzo, Archivio Vasariano (hereafter ACVA), cod. 10 (44), cc. 33, 38. Cf. Gregory, Vasari and the Renaissance Print, 85. Letters from Vasari's correspondence referred to in the following notes are available at Vasari scrittore, URL: http://vasariscrittore.memofonte.it/archivio (accessed on 10 February 2017). On the influence of Giovio in Vasari's intention of illustrating his Lives with the artists' portraits, and on his role in the definition of the entire project, see, to start, Patricia Lee Rubin, Giorgio Vasari: art and history (New Haven and London, 1995), 
106-10; Carlo Maria Simonetti, La vita delle «Vite» vasariane: Profilo storico di due edizioni (Florence, 2005); and Nadia Cannata, “Giorgio Vasari, Paolo Giovio, Portrait Collections and the Rhetorics of Images," in Giorgio Vasari and the Birth of the Museum, ed. Maia Wellington Gahtan (Farnham, 2014), 67-79.

${ }^{3}$ Giorgio Vasari, Le vite de' più eccellenti pittori, scultori e architettori (Florence, 1568) (hencefoth Vite), vol. 2, part III/1, 311: "Per ultimo basti vedere gl'intagli di questo nostro Libro dei ritratti de' pittori, scultori et architetti, disegnati da Giorgio Vasari e dai suoi creati, e state intagliate da maestro Cristofano ... [sic], che ha operato et opera di continuo in Vinezia." The space left blank by Vasari after the cutter's first name suggests that he intended to add his family name later. For discussion of the identity of this "maestro Cristofano," who some have speculated could be either Cristoforo Coriolano or Cristoforo Chriegher, see Gregory, Vasari and the Renaissance Print, 86-8, with further references.

${ }^{4}$ Vasari recorded the date in his Ricordanze. ACVA, cod. 31, c. 24: "Ricordo come questo anno a dì 10 di agosto si cominciò a intagliar le teste de' pittori per fare il libro stampato," available at Vasari scrittore, URL:

http://vasariscrittore.memofonte.it/archivio (accessed on 10 February 2017).

5 This is indicated in Vasari's letter to Vincenzo Borghini of 20 September 1567, preserved in Florence, Archivio di Stato (henceforth ASF), Carteggio d'Artisti, cod. II, ins. 1, c. 52: "E stamani io ho fatto di mia mano il mio viso, ritratto dallo spechio, che non è infiato; et l'ha ritratta nel bossolo. Et se maestro Cristofano a Venezia non lo giostizia, areno una testa graziosa, perché l'ha ritratto bene afatto. Stasera lo manderò a Venezia." 
${ }^{6}$ On Cosimo Bartoli, see the corresponding entry by Roberto Cantagalli and Nicola De Blasi in Dizionario Biografico degli Italiani, available at Treccani, URL:

http://www.treccani.it/biografie/ (accessed on 10 February 2017). See also Judith Bryce, Cosimo Bartoli (1503-1572): the career of a Florentine polymath (Genève, 1983); Francesco Paolo Fiore and Daniela Lamberini, Cosimo Bartoli (1503-1572): atti del convegno internazionale: Mantova, 18-19 novembre-Firenze, 20 novembre 2009 (Florence 2011). Bartoli was also part of the team that corrected the printed text of the Vite: see Brian Richardson, Print Culture in Renaissance Italy: The Editor and the Vernacular Text, 1470-1600 (Cambridge, 1994), 132-3. For the controversial proposal that the Vite be considered a project of fundamentally shared authorship see Charles Hope, "Vasari's Vite as a Collaborative Project," in The Ashgate Research Companion to Giorgio Vasari, ed. David Cast (Burlington, 2014), 11-21.

${ }^{7}$ This was confirmed by Vasari in the Vite in the passage quoted above (note 3).

${ }^{8}$ Cosimo Bartoli to Giorgio Vasari, 15 December 1563, today in ACVA, cod. 11 (45), c. 28; 29 April 1564, today in ACVA, cod. 11 (45), cc. 32, 35; 19 August 1564, today in ACVA, cod. 11 (45), cc. 33-34; 13 September 1567, now in ACVA, cod. 11 (45), c. 48, published in Der literarische Nachlass Giorgio Vasaris, vol. II, ed. Karl Frey (München, 1930), 14-5, 77-9, 107-8, 347-8.

${ }^{9}$ See the excerpt from the letter cited above (note 5 ).

${ }^{10}$ These are the portraits of Lorenzo Bicci and Orcagna, now conserved in GDSU, 638 F; of Andrea Tafi and Gaddo Gaddi, GDSU, 642 F recto; and of Giottino, GDSU, 642 F verso all published in Prinz, "Vasaris Sammlung von Künstlerbildnisses". The drawings on folio $642 \mathrm{~F}$ are available for consultation at Euploos, URL: https://www.polomuseale.firenze.it/gdsu/euploos/ (accessed on 10 February 2017). 
${ }^{11}$ See the letter to Borghini quoted above (note 5).

${ }^{12}$ See especially Cosimo Bartoli's letter of 19 August 1564, cited above (note 8):

"Molto Magnifico messer Giorgio. Io ho ricevuta la vostra de XII et con essa li dua peri, che mi satisfanno pur assai, e son convenuto con maestro Cristofano e li dò di tutto il lavoro scudi 50; e già me ne ha intagliati quattro pezi e va seguitando.”

${ }^{13}$ See especially the letter by Cosimo Bartoli of 13 September 1567, mentioned above (note 8): "ebbi i vostri legni e si son dati a maestro Cristofano e pregatolo, che li intagli presto. Il che mi ha promesso di fare; e subito che li riarò, vi si manderanno."

${ }^{14}$ Cf. previous note. See also the letter from Jacopo Giunti to Vincenzo Borghini, now in Florence, Biblioteca Nazionale Centrale (hereafter BNCF), Filze Rinuccini, 23b/19, fol. 25: "Mando a V.S. 6 figure d'i Ritratti delle Vite de Pittori," quoted, among others, in Gregory, Vasari and the Renaissance Print, 123, note 123. On the role of Vincenzo Borghini - who seems also to have approved at least some of the preparatory drawings - in the production of Vasari's Vite, see especially Robert Williams, "Vincenzo Borghini and Vasari's Lives," (Ph. D. diss., Princeton University, 1988); and - more recently - Idem, "Vasari and Vincenzo Borghini," in The Ashgate Research Companion to Giorgio Vasari, 23-39, with further references.

${ }^{15}$ The preparatory drawings for the portraits, and the one for the frames mentioned here - formerly in Sir Anthony Blunt's collection and now at the Courtauld Institute, London, D.1984.AB.19, accessible online URL: http://www.artandarchitecture.org.uk/images/gallery/ff692147.html (accessed on 10 February 2017) - were studied in detail in Prinz, "Vasaris Sammlung von Künstlerbildnisses”. See also Collobi Ragghianti, 'Il 'Libro de' disegni' ed i ritratti per le "Vite",; Julian Kliemann, “Attribuito a Giorgio Vasari. Tre cornici per i ritratti delle 
'Vite','in Principi, letterati e artisti, 238-42; Gregory, Vasari and the Renaissance Print, 83-114.

${ }^{16}$ Vite, Proemio, vol. 1, part I, 81: “e se d'alcuno mancasse il ritratto, ciò non è per colpa mia, ma per non si essere in alcuno luogo trovato." On these absences - for which a vast bibliography has arisen - see, to start, Maria H. Loh, Still Lives: Death, Desire, and the Portrait of the Old Master (Princeton, 2015), 19-25, with further references.

${ }^{17}$ On the variety of publications utilizing these portraits see Lisa Pon, "Lives and Afterlives of Vasari's Portraits of the Artists," in Dear Print Fan: A Festschrift for Marjorie B. Cohn, eds. Craigen Bowe, Susan Dackerman, and Elizabeth Mansfield (Cambridge, 2001), 243-8; and, most recently, Loh, Still Lives, ix-xv.

${ }^{18}$ On this edition (hencefoth Ritratti) see, above all, Charles Davies, "Giorgio Vasari, Ritratti de' più eccellenti pittori, scultori et architetti [...]," in Giorgio Vasari. Principi, letterati e artisti, 257-9; Eliana Carrara, “Giorgio Vasari, Ritratti de’ più eccellenti pittori, scultori et architetti [...]," in: Vasari, gli Uffizi e il Duca, exh. cat., ed. Claudia Conforti (Florence and Milan, 2011), 385; Gregory, Vasari and the Renaissance Print, 122 , note 109 , with further references.

${ }^{19}$ Likewise, an offprint of the life of Jacopo Sansovino was printed by an unknown publisher, albeit with a recut portrait. On these offprints and their relationship to the Vite and its reading public see esp. Lisa Pon, “Michelangelo's Lives: Sixteenth-Century Books by Vasari, Condivi, and Others," The Sixteenth Century Journal 27 (1996): 1015-37, 1024-30. See also Eliana Carrara, "Giorgio Vasari, Vita del gran Michelagnolo Buonarroti [...]," in Vasari, gli Uffizi e il Duca, 391, with further references.. 
${ }^{20}$ Giorgio Vasari, Trattato della pittura del S. Cavaliere Giorgio Vasari Pittore, \& Architetto, Nel quale si contiene, la Prattica di essa, Divisato in tre giornate (Florence, 1619).

${ }^{21}$ On the Giunti see esp. William A. Pettas, The Giunti of Florence: a Renaissance printing and publishing family. A history of the Florentine firm and a catalogue of the editions (New Castle, 2013).

${ }^{22}$ Effigie di celebri pittori, scultori et architetti la cui vita fu descritta dal signor Giorgio Vasari (Florence, 1629), dedicatory letter by Simone Ciotti addressed to "Sig. Lodovico Peruzzi”: "Di qui avvenne, che il famosissimo Sig. Giorgio Vasari [...] ridusse in un libro, \& in piccoli ovati l'effigie [de' valorosi Pittori] al naturale intagliate [...]. Queste ritrovandosi appresso di me, ho voluto ridurre in ampio foglio, e con più facilità rappresentarle al guardo altrui." Among the few copies of this edition that are known today, one is preserved in Paris, Bibliothèque nationale de France, Département Estampes et photographie, 4-NB-29, available online URL: http://gallica.bnf.fr/ark:/12148/btv1b84539860 (accessed on 10 February 2017); and another in Florence, Kunsthistorisches Institut, H 79 m (RARO). They present a different page layout. See especially Loh, Still Lives, x, and fig. I.1, xi. See also Georg Kauffmann, "Vasari: Poussin," Mitteilungen des Kunsthistorischen Institutes in Florenz VIII/4 (1959): 252-6.

${ }^{23}$ Le vite de' più Eccellenti Pittori, Scultori et Architetti. Di Giorgio Vasari Pittore, \& Architetto Aretino. Parte Prima, e Seconda. In questa nuova edizione diligentemente riviste, ricorrette, accresciute d'alcuni Ritrati, \& arricchire di postille nel margine. Carlo Manolessi in this edition completed the frames left empty by Vasari with the corresponding portraits. Loh, Still Lives, 20-1; Pon, “Lives and Afterlives," esp. 247-8. 
${ }^{24}$ Licia Collobi Ragghianti, Il Libro de’ disegni del Vasari, 2 vols (Florence 1974), 11, with reference to the life of Lorenzo Ghiberti in Vite, vol. 1, part II, 186: "Furono i disegni di Lorenzo eccellentissimi e fatti con gran rilievo, come si vede nel nostro libro de' disegni in uno Evangelista di sua mano et in alcuni altri di chiaro scuro bellissimi. Disegnò anco ragionevolmente Bartoluccio suo padre, come mostra una altro Vangelista di sua mano in sul detto libro, assai men buono che quello di Lorenzo. I quali disegni con alcuni di Giotto e d'altri ebbi, essendo giovanetto, da Vettorio Ghiberti l'anno 1528, e gl'ho sempre tenuti e tengo in venerazione e perché sono belli e per memoria di tanti uomini."

${ }^{25}$ Among the vast bibliography, see esp. Alphonse Wyatt, “Le 'Libro dei Disegni’ du Vasari," Gazette des Beaux-Arts 4 (1859): 339-51; Otto Kurz, “Giorgio Vasari’s Libro de’ Disegni," Old Master Drawings XI/45 (1937): 1-15; XII/47 (1937): 32-44;

Bernhard Degenhart and Annegrit Schmitt, "Methoden Vasaris bei den Gestaltung seines Libro," Studien zur toskanischen Kunst, Festschrift für Ludwig Heinrich Heydenreich zum 23 März 1963, eds. Wolfgang Lotz and Lise Lotte Möller (München, 1964), 45-64; Bernhard Degenhart and Annegrit Schmitt, Corpus der Italianischen Zeichnungen 1300-1450 (Berlin, 1968); Catherine Monbeig Goguel and Roseline Bacou, Giorgio Vasari: Dessinateur et Collectionneur, exh. cat., Paris 1965; Collobi Ragghianti, Il Libro de' disegni; Hellmut Wohl, “The Eye of Vasari," Mitteilungen des Kunsthistorischen Institutes in Florenz XXX/3 (1986): 537-68; Per Bjürstrom, Italian drawings from the collection of Giorgio Vasari (Stockholm, 2001).

${ }^{26}$ For examples of Vasari's own references to his 'Libro de' disegni”" see Vite, vol. 1, part I, 123, 131, 156, 231; vol. 1, part II, 270, 286, 443; vol. 2, part III/1, 2, 40; vol. 3, part III/2, 380, 674, 718 . 
${ }^{27}$ See, among others, Kimberly Schenck et alii, “A page form Giorgio Vasari’s 'Libro de' disegni' as a composite object," Facture: conservation, science, art history 1 (2013): 2-31. See also Restauro e conservazione delle opere d'arte su carta, Cataloghi del Gabinetto Disegni e Stampe degli Uffizi, 56 (Florence, 1981). Andrew Morrogh is currently working on the frames used to decorate the pages of Vasari's Libro de' disegni, and we refer to future publications of this author. See his lecture "Niccolò Gaddi and Giorgio Vasari," 5 March 2016, Center for the History of Collecting at the Frick Collection, URL:

http://www.frick.org/interact/andrew_morrogh_niccolò_gaddi_and_giorgio_vasari (accessed on 10 February 2017).

${ }^{28}$ (1) London, British Museum, no. 1895,0915.807 recto, with portrait of Vittore Carpaccio, for which see Collobi Ragghianti, Il Libro de' disegni, vol. I, 89 and vol. II, fig. 244; Nicholas J. L. Turner, Florentine Drawings of the Sixteenth Century (London, 1986), no. 143, 190-1. (2) Oxford, Christ Church College, no. 1338 recto, with portrait of Filippino Lippi, for which see Collobi Ragghianti, Il Libro de’ disegni, vol. I, 85 and vol. II, fig. 240; Principi, letterati e artisti, Section VIII, no. 5, 249-50, fig. 187; James Byam Shaw, Drawings by Old Masters at Christ Church Oxford (Oxford, 1976), vol. II, 42-3, and plates 41-2. (3) Paris, École des Beaux-Arts, no. 381 recto, with portrait of Cimabue, for which see Collobi Ragghianti, Il Libro de' disegni, vol. I, 26 and vol. II, fig. 11; Erwin Panofsky, “The First Page of Giorgio Vasari’s 'Libro': A Study on the Gothic Style in the Judgment of the Italian Renaissance," idem, Meaning in the visual arts: papers in and on art history (Chicago, 1955), 169-236; Claus Virch, “A Page from Vasari's Book of Drawings," The Metropolitan Museum of Art Bulletin XIX/7 (1961): 185-93. (4) Chatsworth, Duke of Devonshire collection, no. 963 recto, with portrait of 
Nanni di Banco, for which see Collobi Ragghianti, Il Libro de' disegni, vol. I, 45 and vol. II, fig. 59; Michael W. Cole, "Why Did Sculptors Draw?” Donatello, Michelangelo, Cellini. Sculptors' Drawings from Renaissance Italy, ed. idem (Boston and London, 2014), 14, fig. 1. (5) Chatsworth, Duke of Devonshire collection, no. 962 recto, with portrait of Luca della Robbia, Collobi Ragghianti, Il Libro de' disegni, vol. I, 45 and vol. II, fig. 62. (6) London, British Museum, no. 1882,0812.218 recto, with empty portrait, drawings attributed to Tommaso di Cristofano detto Masolino, for which see Collobi Ragghianti, Il Libro de’ disegni, vol. I, 50 and vol. II, fig. 93; Turner, Florentine Drawings, no. 142, 189-90. (7) Chatsworth, Duke of Devonshire collection, no. 961 recto, with portrait of Alesso Baldovinetti, for which see Collobi Ragghianti, Il Libro de' disegni, vol. I, 58 and vol. II, fig. 129; Principi, letterati e artisti, Section VIII, no. 4, 248, fig. 190. (8) Louvre, Cabinet des Dessins, INV 1724 recto, with portrait of Andrea del Sarto, for which see Collobi Ragghianti, Il Libro de' disegni, vol. I, 115 and vol. II, fig. 304. (9) Louvre, Cabinet des Dessins, INV 1202 recto, with portrait of Franciabigio, for which see Collobi Ragghianti, Il Libro de' disegni, vol. I, 121 and vol. II, fig. 377. Cf. also, for the drawings now at the Louvre, Catherine Monbeig Goguel, "Taste and Trade: The Retouched Drawings in the Everard Jabach Collection at the Louvre," The Burlington Magazine CXXX/1028 (1988): 821-35; Eadem, "Quelques observations sur la pratique des retouches dans le dessin. Retour sur le cas des dessins de la collection Jabach au musée du Louvre," Artibus et Historiae XXXI/ 62, part II (2010): 103-14.

${ }^{29}$ Since the frames used for Filippino Lippi's portrait differed between the Vite and the Ritratti, it is clear that the print affixed to this sheet is more directly related to the latter project. On these variations, see the following note and, below, note 36 . 
${ }^{30} \mathrm{Cf}$. the sources mentioned above (note 28 ), as well as the previous note. See also Kimberly Schenck et alii, “A page form Giorgio Vasari’s 'Libro',” 6; Davies, “Giorgio Vasari, Ritratti," 258, with further references. Sometimes these portraits have also been referred to as proofs: see Pon, "Lives and Afterlives," 245 and 249, note 17; Gregory, Vasari and the Renaissance Print, 122, note 109, with further bibliography.

${ }^{31}$ On the Ritratti see, in addition to that mentioned above (note 18), also Sharon Gregory, "'The outer man tends to be a guide to the inner': the woodcut portraits in Vasari's 'Lives' as parallel texts," in The Rise of the Image. Essays on the History of the Illustrated Art Book, eds. Rodney Palmer and Thomas Frangenberg (Aldershot, 2003), 51-85: 53 and note 14. On the 1568 editions of the Vite and the Ritratti, see also Pettas, The Giunti of Florence, 509-12.

${ }^{32}$ Biblioteca Berenson, Villa I Tatti, Harvard University, Special Collections N6923.V32 1568 M; New York Public Library, Spencer Coll. Ital. 1568; Houghton Library, Harvard University, Typ 525.68.866.

${ }^{33}$ See, among the vast bibliography, esp. Tommaso Casini, Ritratti parlanti. Collezionismo e biografie illustrate nei secoli XVI e XVII (Florence, 2004), 19-32; Wendy Thomson, “Antonfrancesco Doni's 'Medaglie'," Print Quarterly, XXIV/3 (2007): 223-38, with further references.

${ }^{34}$ The publication is described as "Ritratti de Pittori è Scultori. 4": Catalogus librorum qui in Iunctarum bibliotheca Philippi haeredum Florentiae prostant (Florence, 1604), 528. Copy consulted: BNCF, Magl. 12.8.323. Cf. Pettas, The Giunti of Florence, 72930.

${ }^{35}$ On bookbinding practices in Renaissance Italy, see the work of Anthony Hobson, esp. Humanists and Bookbinders: The origins and Diffusion of the Humanistic Bookbinding 
(Cambridge, 1992). See also Julia Miller, Books will speak plain: a handbookfor identifying and describing historical bindings (Ann Arbor, 2014); Mirjam M. Foot, Bookbinders at work: their roles and methods (London and New Castle, 2006); Paul Needham, Twelve centuries of bookbindings, 400-1600 (New York and London, 1979). ${ }^{36}$ Ritratti, no. 37; Vite, vol. 1, part II, 274. Other examples of variations of frames between the editions are Fra Filippo Lippi (Ritratti, no. 53; Vite, vol. 1, part II, 385), Filippino Lippi (Ritratti, no. 76; Vite, vol. I, part II, 492), for which see also, above, note 29; Vittore Carpaccio (Ritratti, no. 80; Vite, vol. 1, part II, 517); Pordenone (Ritratti, no. 108; Vite, vol. 2, part III/1, 182).

${ }^{37}$ On these printing practices see esp. Elizabeth Savage (published as Elizabeth Upper), "Red Frisket Sheets, ca. 1490-1700: The Earliest Artifacts of Color Printing in the West," Papers of the Bibliographical Society of America 108 (2014): 477-522.

${ }^{38}$ Ritratti, no. 34 .

${ }^{39}$ Ritratti, nos $1,2$.

${ }^{40}$ On Clarici's role in these projects see esp. Marino Viganò, "Iconografia del Castello Sforzesco nell'epoca delle grandi fabbriche (1551-1656)," Arte Lombarda 120 (1997): 44-54; and Viganò, "Le mura di Cremona (1584-1596): I progetti di Giovan Battista Clarici, Giovan Giocomo Paleari Fratino e Tiburzio Spannocchi,” Arte Lombarda 121 (1997): 67-78, with further references.

${ }^{41}$ L'aggiunta dell'Historia universale et delle cose di Milano: "gran libratore d'acque, de fiumi, de laghi, di fortezze, di monti e di paesi," cited by Aurora Scotti Tosini, “Lorenzo Binago e Francesco Maria Ricchino tra Milano e Roma," Arte Lombarda 134 (2002): 96-103: 102, note 7; and Giovanni Paolo Lomazzo, Trattato dell'arte della 
pittura, scultura et architettura (Milan, 1585), 255: “Architetto et pigliator di distanze, altezze e profondità di monti, colli ed acque."

${ }^{42}$ The note appears on the verso of a sheet with four sketches of the Madonna and Child attributed to Federico Barocci, today GDSU 11447 F, available for consultation through Euploos, URL: https://www.polomuseale.firenze.it/gdsu/euploos/ (accessed on 10 February 2017). For this drawing, see Andrea Emiliani, Federico Barocci (Urbino 1535-1612), 2 vols (Ancona, 2008), vol. 1, no. 2013. On Marchetti, among Vasari's most significant collaborators at the Palazzo Vecchio see, to start, Alessandro Cecchi and Ugo Muccini, Le Stanze del Principe in Palazzo Vecchio (Florence, 1991).

${ }^{43}$ On the possible use of the Ritratti, see also Gregory, Vasari and the Renaissance Print, 122, note 109; and Pon, "Lives and Afterlives".

${ }^{44}$ See especially Adrian Johns, The Nature of the Book: Print and Knowledge in the Making (Chicago, 1998). On booksellers see Michael F. Suarez and Henry. R. Woudhuysen eds, The Oxford Companion to the Book (Oxford, 2010); and Andrew Pettegree, The Book in the Renaissance (New Haven and London, 2010), with further references. See also Brigitte Manéra-Payrou, Rémy Calavéra and Francesca Fabre eds, La librairie: actes de la Huitième Journée d'Étude sur l'Imprimerie (Perpignan le 30 avril 2010), (Perpignan, 2011); Robin Myers, Michael Harris and Giles Mandelbrote eds, Books for sale: the advertising and promotion of print since the fifteenth century (London and New Castle, 2009); Graham Pollard and Albert Ehrman, The distribution of books by catalogue from the invention of printing to A.D. 1800 (Cambridge, 1965). ${ }^{45}$ See esp. Nadia Cannata, "Giorgio Vasari, Paolo Giovio, Portrait Galleries and the Rhetorics of Images," in Maia Wellington Gahtan ed., Giorgio Vasari and the Birth of the Museum (Farnham and Burlington, 2014), 67-79; Casini, Ritratti parlanti. 
${ }^{46}$ On this map (today in the Biblioteca dell'Accademia di San Luca, Rome) see Viganò, "Iconografia del Castello Sforzesco."

${ }^{47}$ GDSU 11447 F verso: "Questo Città di Fiorenza mi piace assai e non vi voglio stare mancho d'un mese, per vederla ben tutta compitamente et potervi dar ragguaglio de le tutte le bell'opere, tanto de pittu[ra], come di scoltura [...] e per potermi meglio ms Giorgio d'Arezzo me fà lavorarre con Marco da Faenza, il quale a me pare che lui lavori molto bene di grotesche." See above, note 42, for further references.

${ }^{48}$ UCL Art Museum, Acc. nos 2474 (portrait of Alfonso Lombardi) and 2475 (portrait of Nicola Pisano).

${ }^{49}$ Ritratti, no. 86; Vite, vol. 2, part III/1, 27.

${ }^{50}$ Ritratti, no. 99; Vite, vol. 2, part III/1, 123.

${ }^{51}$ Ritratti, no. 61; Vite, vol. 1, part II, 416.

${ }^{52}$ Ritratti, no. 91; Vite, vol. 2, part III/1, 55.

${ }^{53}$ Ritratti, no. 138; Vite, vol. 3, part III/2, 536.

${ }^{54}$ Ritratti, no. 98; Vite, vol. 2, part III/1, 116.

${ }^{55}$ Ritratti, no. 103; Vite, vol. 2, part III/1, 137.

${ }^{56}$ Ritratti, no. 124; Vite, vol. 2, part III/1, 312.

${ }^{57}$ This document is now preserved in Florence, Archivio Storico delle Gallerie Fiorentine, file XXIX, doc. 7, published in Licia Collobi Ragghianti, "Nuove precisazioni sui disegni di architettura del 'Libro' del Vasari," Critica d'arte, n. s., XX/130 (1973): 31-54, esp. 31-2.

${ }^{58}$ Cf., in particular, Collobi Ragghianti, "Nuove precisazioni."

${ }^{59}$ This was, in all likelihood, the collector Willem Anne Lestevenon, for which see Carel van Tuyll van Serooskerken, The Italian Drawings of the Fifteenth and Sixteenth 
Centuries in the Teyler Museum, (Haarlem, Ghent and Doornspijk, 2000); Béatrice de Moustier, "The Italian Drawings Collection of the Marquis de Lagoy," Master Drawings, 2 (2008): 187-204, esp. 193-8.

${ }^{60}$ Ibidem: "La maggiore e miglior parte dei disegni spettavano a Giorgio Vasari, il quale come egli medesimo ci attesta al termine di quasi tutte le vite da lui scritte degli Artefici, ne aveva formato un gran Libro, che poi fu distrutto e disperso in molte parti [...]. Prova di ciò ne fanno gli ornamenti d'acquerello da Giorgio medesimo con molta abilità condotti intorno a ciascun foglio, e il ritratto di fronte dell'artefice, a cui appartiene il disegno. Mi sovviene averne veduti alcuni così fatti nella raccolta del Barone Lestewenon Olandese, che gli aveva acquistati a gran prezzo nella vendita Mariette e se gli teneva carissimi.”

${ }^{61}$ As regards the portrait of Andrea Contucci (known as Sansovino), which is cropped around the oval, see - for comparison - the sheet now in Chatsworth, Duke of Devonshire collection, no. 962 recto, with portrait of Luca della Robbia. Collobi Ragghianti, Il Libro de' disegni, vol. I, 45 and vol. II, fig. 62. Cf. above, notes 28 and 54.

${ }^{62}$ Collobi Ragghianti, "Nuove precisazioni,” $34 \mathrm{f}$.

63 “1408. Autre grand Volume in-folio, relié en veau fauve, de soixante feuilles, contenant plus de cent différents morceaux d'Architecture \& Etudes de figures, faits à la plume \& au bistre, par Antoine \& Julien Sangallo \& autres Architectes \& Sculpteurs Florentins, avec leurs Portraits en tête de leurs ouvrages." See La vente Mariette. Le catalogue illustré par Gabriel de Saint-Aubin, repr. facs. (Milan, 2011), 214. 
${ }^{64}$ See especially Licia Collobi Ragghianti, “Il 'Libro de’ disegni’ del Vasari: disegni di architettura," Critica d'arte, n. s., XX/127 (1973): 3-120; Collobi Ragghianti, "Nuove precisazioni," 40f.

${ }^{65}$ On this topic, see the lecture by Andrew Morrogh previously mentioned (note 27). On Niccolò Gaddi’s collections, see esp. Cristina Acidini, "Niccolò Gaddi collezionista e dilettante del Cinquecento," Paragone Arte, XXXI/ 359-61 (1980): 141-75; and, most recently, Laura Moretti, “The palazzo, collections, and musical patronage of Niccolò Gaddi (1536-91)," Journal of the History of Collections, Advance Access published 27 April 2016.

${ }^{66}$ Cf. Gregory, Vasari and the Renaissance Print, 122, note 109; Pon, "Lives and Afterlives," esp. 245.

${ }^{67}$ Vite, vol. 1, part I, 418, Vita di Desiderio da Settignano: "Nel nostro libro sono alcune carte disegnate di penna da Desiderio, bellissime"; vol. 2, part III/1, 31. Vita di Bramante: “Andò Bramante ne servitii di questo pontefice a Bologna quando l'anno 1504 ella torno alla chiesa \& si adoperò in tutta la Guerra della Mirandola a molte cose ingegnose, e di grandissima importanza fe molti disegni di piante e di edifitii che molto bene erano disegnati da lui come nel nostro libro ne appare alcuni ben misurati et fatti con arte grandissima"; 118, Vita di Andrea Sansovino: "Per queste, e per l'altre opere d'Andrea divolgatosi il nome suo, fu chiesto al Magnifico Lorenzo vecchio de' Medici, nel cui giardino havea come si è detto atteso agli studi del disegno, dal Re di Portogallo; perche mandatogli da Lorenzo lavorò per quel Re molte opere di scultura, e d'architettura, e particolarmente un bellissimo palazzo con quattro torri, \& altri molti edifizij. Et una parte del palazzo fu dipinta secondo il disegno, \& cartoni di mano d'Andrea, che disegnò benissimo, come si puo vedere nel nostro libro in alcune carte di 
sua propria mano, finite con la punta d'un carbone, con alcune altre carte d'architettura benissimo intesa"; 125, Vita di Benedetto da Rovezzano: "Il suo ritratto si è cavato da uno che fu fatto, quando egli era giovane, da Agnolo di Donino, il quale proprio è in sul nostro libro de' disegni, dove sono anco alcune carte di mano di Benedetto molto ben disegnate: il quale per queste opere merita di essere fra questi eccellenti artefici annoverato"; 144, Vita di Baldassarre Peruzzi: "Disegnò Baldassarre eccellentemente in tutt'i modi, e con gran giudizio e diligenza, ma più di penna, d'acquerello e chiaro scuro che d'altro, come si vede in molti disegni suoi che sono appresso gl'artefici, e particolarmente nel nostro libro in diverse carte"; vol. 3, part III/2, 544, Vita di Bastiano detto Aristotile da Sangallo: "Nel nostro Libro sono alcuni disegni di mano d'Aristotile, et alcuni ne sono appresso Antonio Particini, fra i quali sono alcune carte tirate in prospettiva, bellissime."

${ }^{68}$ See also, among the vast bibliography on the subject, Catherine Goguel, Vasari et son temps: maîtres toscans nés après 1500, morts avant 1600 exh. cat. Musée du Louvre (Paris,1972); and Florian Härb, The drawings of Giorgio Vasari (1511-1574) (Rome, 2015).

${ }^{69}$ See Charles Davis, 'Frescos by Vasari for Sforza Almeni, 'Coppiere' to Duke Cosimo I," Mitteilungen des Kunsthistorichen Institutes in Florenz 24 (1980): 127-202. 


\section{Figure legend}

Figure 1. Giorgio Vasari, Portraits of Lorenzo di Bicci and Andrea Orcagna. (Florence, Gabinetto Disegni e Stampe degli Uffizi, 638 F.)

Figure 2. Portrait of Andrea Orcagna. From Giorgio Vasari, Le vite de' piu eccellenti pittori, scultori, e architettori (Florence, 1568).

Figure 3. Portraits of Taddeo Gaddi and Andrea Orcagna. From Giorgio Vasari, Ritratti de' più eccellenti pittori, scultori et architetti (Florence, 1568).

Figure 4. Portraits of Ambrogio Lorenzetti, Simone Martini, Taddeo Gaddi, and Andrea Orcagna. From Effigie di celebri pittori, scultori et architetti la cui vita fu descritta dal signor Giorgio Vasari (Florence, 1629).

Figure 5. Portrait of Andrea Orcagna. From Giorgio Vasari, Le vite de' piu eccellenti pittori, scultori, e architettori (Bologna, 1647).

Figure 6. Filippino Lippi and Assistants, Various Studies. (Oxford, Christ Church, no. 1338 recto.)

Figure 7. Portrait of Filippo Lippi (called Filippino). Detail of Figure 6 (Oxford, Christ Church, no. 1338 recto.)

Figure 8. Title page. From Giorgio Vasari, Ritratti de' più eccellenti pittori, scultori et architetti (Florence, 1568), with detail of Giovanni Battista Clarici's signature (New York, New York Public Library).

Figure 9. Portrait of Bramante. (Florence, Gabinetto Disegni e Stampe degli Uffizi, 12399.)

Figure 10. Portrait of Benedetto da Rovezzano. (Florence, Gabinetto Disegni e Stampe degli Uffizi, 12400.)

Figure 11. Portrait of Andrea Contucci (known as Sansovino). (Florence, Gabinetto 
Disegni e Stampe degli Uffizi, 12401.)

Figure 12. Portrait of Desiderio di Settignano. (Florence, Gabinetto Disegni e Stampe degli Uffizi, 12402.)

Figure 13. Portrait of Baldassarre Peruzzi. (Florence, Gabinetto Disegni e Stampe degli Uffizi, 12403.)

Figure 14. Portrait of Giuliano da Sangallo. (Florence, Gabinetto Disegni e Stampe degli Uffizi, 12404.)

Figure 15. Portrait of Bastiano (called Aristotile) da Sangallo. (Florence, Gabinetto Disegni e Stampe degli Uffizi, 12405.)

Figure 16. Portrait of Antonio da Sangallo. (Florence, Gabinetto Disegni e Stampe degli Uffizi, 12406.)

Figure 17. Portrait of Bramante. From Giorgio Vasari, Ritratti de' più eccellenti pittori, scultori et architetti (Florence, 1568).

Figure 18. Portrait of Bramante. From Giorgio Vasari, Le vite de' piu eccellenti pittori, scultori, e architettori (Florence, 1568).

Figure 19. Portrait of Benedetto da Rovezzano. From Giorgio Vasari, Ritratti de' più eccellenti pittori, scultori et architetti (Florence, 1568).

Figure 20. Portrait of Benedetto da Rovezzano. From Giorgio Vasari, Le vite de ' piu eccellenti pittori, scultori, e architettori (Florence, 1568).

Figure 21. Portrait of Desiderio da Settignano. From Giorgio Vasari, Ritratti de’ più eccellenti pittori, scultori et architetti (Florence, 1568).

Figure 22. Portrait of Desiderio da Settignano. From Giorgio Vasari, Le vite de' piu eccellenti pittori, scultori, e architettori (Florence, 1568).

Figure 23. Portrait of Giuliano da Sangallo. From Giorgio Vasari, Ritratti de' più eccellenti pittori, scultori et architetti (Florence, 1568). 
Figure 24. Portrait of Giuliano da Sangallo. From Giorgio Vasari, Le vite de’ piu eccellenti pittori, scultori, e architettori (Florence, 1568).

Figure 25. Portrait of Bastiano (called Aristotile) da Sangallo. From Giorgio Vasari, Ritratti de' più eccellenti pittori, scultori et architetti (Florence, 1568).

Figure 26. Portrait of Bastiano (called Aristotile) da Sangallo. From Giorgio Vasari, Le vite de' piu eccellenti pittori, scultori, e architettori (Florence, 1568).

Figure 27. Portrait of Andrea Contucci (known as Sansovino). From Giorgio Vasari, Ritratti de' più eccellenti pittori, scultori et architetti (Florence, 1568).

Figure 28. Portrait of Andrea Contucci (known as Sansovino). From Giorgio Vasari, Le vite de' piu eccellenti pittori, scultori, e architettori (Florence, 1568).

Figure 29. Portrait of Baldassarre Peruzzi. From Giorgio Vasari, Ritratti de’ più eccellenti pittori, scultori et architetti (Florence, 1568).

Figure 30. Portrait of Baldassarre Peruzzi. From Giorgio Vasari, Le vite de' piu eccellenti pittori, scultori, e architettori (Florence, 1568).

Figure 31. Portrait of Antonio da Sangallo. From Giorgio Vasari, Ritratti de’ più eccellenti pittori, scultori et architetti (Florence, 1568).

Figure 32. Portrait of Antonio da Sangallo. From Giorgio Vasari, Le vite de' piu eccellenti pittori, scultori, e architettori (Florence, 1568).

Figure 33. Giorgio Vasari, Study for the frontispiece of Leon Battista Alberti, L'Architettura (Florence, 1550). (Florence, Gabinetto Disegni e Stampe degli Uffizi, 394 O.) 